\title{
Three New Varieties in Ocimum L. (Lamiaceae)
}

\author{
Ulysses P. de Albuquerque \\ Laboratório de Etnobotânica e Botânica Aplicada, Departamento de Botânica, Centro de Ciências Biológicas, \\ Universidade Federal de Pernambuco - Av. Prof. Nelson Chaves s/n. Cidade Universitária, CEP 50670-420, \\ Recife Pernambuco, Brasil.
}

\begin{abstract}
Three new infraspecifc taxa in Ocimum are described from Northeastern Brazil, which were based in vegetative morphology, habit, stem indumentum or purple pigmentation; these were O. minimum var. religiosum Albuquerque var. nov., O. campechianum var. pubescens Albuquerque var. nov. and O. campechianum var. congestifolium Albuquerque var. nov.
\end{abstract}

Key words: Ocimum, Lamiaceae, new varieties.

\section{INTRODUCTION}

The taxonomy of the genus Ocimum L. is based essentially on morphological characters of the inflorescence, flowers and leaves. The indumentum has been used to distinguish infraspecific taxa and to help separate taxa which are vegetatively very similar (Paton, 1992; Albuquerque \& Andrade, 1998a).

The first complet taxonomic survey of the genus in Brazil was made by Schmidt (1858) in the Flora Brasiliensis. A century later, Pereira (1972) presented a key to species in Brazil, but excluding one species previously recognized by Schmidt (1858) $(O$. tweedianum Benth.), and describing $O$. transamazonicum C. Pereira: O. americanum L. (=O. canum $\mathrm{Sims}), O$. gratissimum L., $O$. nudicaule Benth., O. selloi Benth. (=O. sellowii Benth and $O$. carnosum Lk. et Otto), O. campechianum Mill. (=O. micranthum Willd.), O. procurrens Epling and $O$. ovatum Benth. No comprehensive taxonomic treatment of the entire genus in Brazil has appeared since that by Schmidt (1858). Albuquerque \& Andrade (1998b), recognized 12 species in Brazil and analysed the infraespecific variation in some species
(Albuquerque \& Andrade, 1998a; Albuquerque, 1998).

Studies of the plants in traditional markets in Recife (Pernambuco) revealed the existence of a new variety of $O$. minimum L., an species widely cultivated throughout the world. Study of the herbarium collections at the herbaria ALCB and IPA (herbarium codes following Holmgreen et al, 1990) yielded two new varieties of Ocimum campechianum Mill. These varieties are formally described and named in this paper.

\section{RESULTS AND DISCUSSION}

Ocimum minimum var. religiosum Albuquerque var. nov., sed caule, foliis, inflorescentia, calyce et corolla valde purpurascentibus differt.Typus: Brazil, Pernambuco, Recife, Arruda, 21 april 1993, Albuquerque 16 (Holotypus UFP). Herb with compact bushy habit. Stem very purple. Leaves small, usually shorter than $2.5 \mathrm{~cm}$ long, purple. Inflorescence branched, bracts purple. Calyx purple. Corolla purple. (Fig.1)

Vernacular name: mangericão roxo

Note: $O$. minimum var. religiosum shows characters intermediate between those of $O$. 
minimum L. and $O$. basilicum var. purpuracens Benth. It differs from the former essentially by the intensely purple colour of the whole plant and from $O$. basilicum var. purpuracens Benth. by dense habit and smaller leaves. The specific epithet is an allusion to the plant's use for ritual bathing in Afrobrazilian religion.

Ocimum campechianum var. pubescens Albuquerque var. nov., indumento caulis et ramis pubescenti, pilis rectis retrorsisque in lateribus oppositis dispositis, aliis varietatibus differt. Typus: Brazil, Bahia, Tareco, Morro do Chapéu, 15 may 1957, Lordêlo 402 (Holotypus ALCB). Stem pubescent below with straight and retrorse hairs concentrated on two opposing stem faces, \pm all around above. Leaves pubescent all over or hairs concentrated on veins. (Figs. $2,4)$

Vernacular name: alfavaco grande.
Other material: Brazil, Bahia, Irecê, Alto da Gabriela, 10 may 1984, Fotius 3847 (IPA).

Ocimum campechianum var. congestifolium Albuquerque var. nov., foliis in fasciculis congestis aliis varietatibus differt.Typus: Brazil, Bahia, Irecê, Lagoa dos Patos, 20 aug. 1980, Bastos 15 (Holotypus ALCB). Stem glabrous below, pubescent on nodes and branches or not with retrorse and straight hairs. Leaves in denses fascicles, pubescent or subglabrous with hairs concentrated on veins. (Figs. 3,4)

Vernacular name: alfavaca-de-cobra, alfavaca.

Note: $O$. campechianum var. pubescens differs from the type variety by the pubescent indumentum of the stem. Var. congestifolium is distinguished by the leaves arranged in dense fascicles. Table 1 shows the main differences between the varieties of this species.

Table 1. Differences between varieties of $O$. campechianum Mill.

\begin{tabular}{lllc}
\hline $\begin{array}{c}\text { TAXA } \\
\text { O. campechianum }\end{array}$ & \multicolumn{1}{c}{$\begin{array}{c}\text { LEAF } \\
\text { INDUMENTUM }\end{array}$} & $\begin{array}{l}\text { STEM INDUMENTUM } \\
\text { (below inflorescence) }\end{array}$ & $\begin{array}{c}\text { LEAF } \\
\text { ARRANGEMENT }\end{array}$ \\
\hline var. campechianum & Subglabrous & $\begin{array}{l}\text { glabrous or subglabrous } \\
\text { with scattered short } \\
\text { adpressed and retrorse hairs }\end{array}$ & dispersed \\
var. pubescens & Pubescent & $\begin{array}{l}\text { pubescent with straight and } \\
\text { retrorse hairs }\end{array}$ & dispersed \\
var. congestifolium & $\begin{array}{l}\text { pubescent or } \\
\text { subglabrous }\end{array}$ & $\begin{array}{l}\text { Glabrous below, sometimes } \\
\text { with retrorse and straight } \\
\text { hairs on nodes and } \\
\text { branches. }\end{array}$ & \\
& & & in dense fascicles \\
& &
\end{tabular}




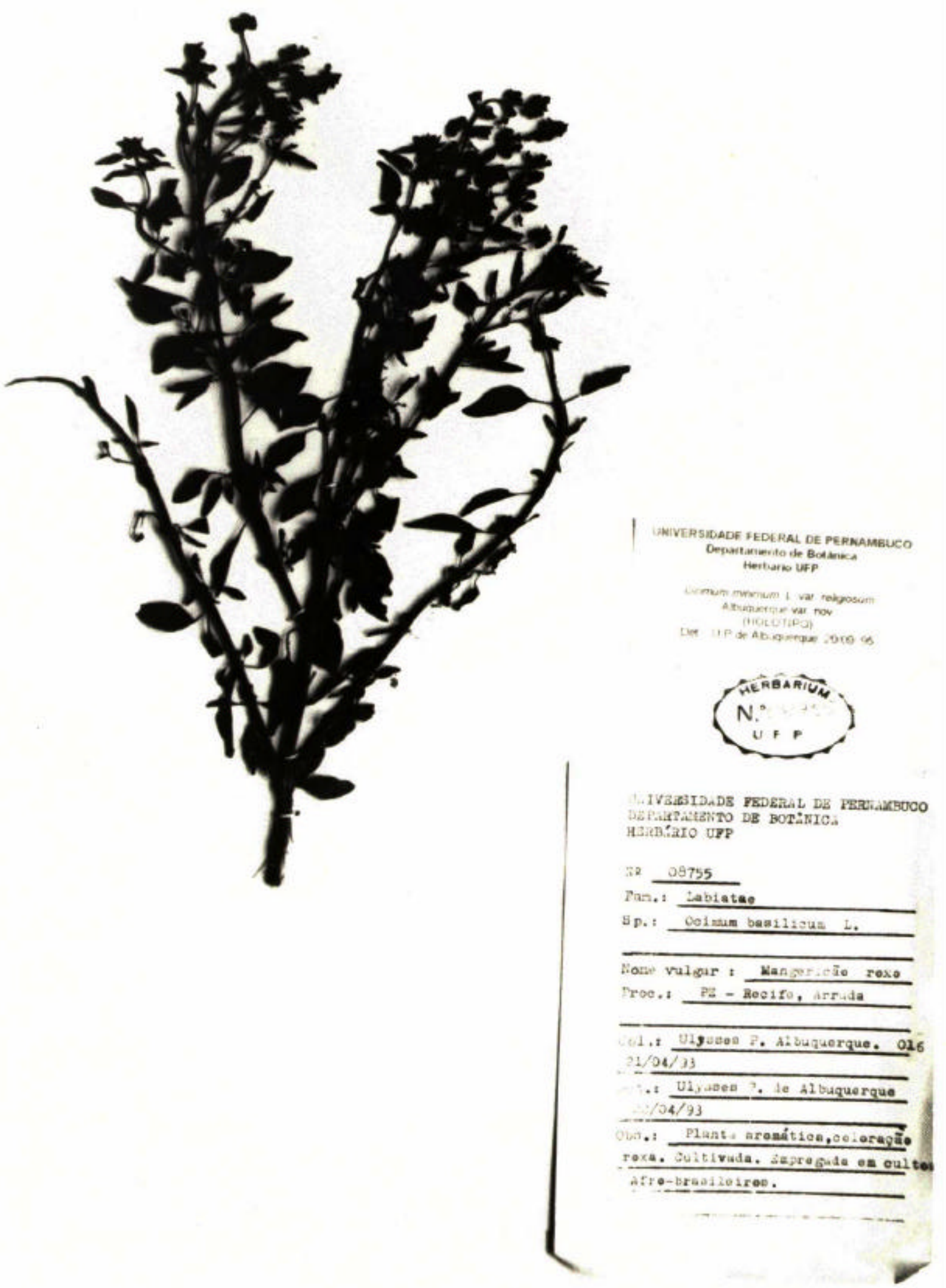

Fig. 1. Ocimum minimum var. religiosum Albuquerque var. nov. (Holotypus UFP). 


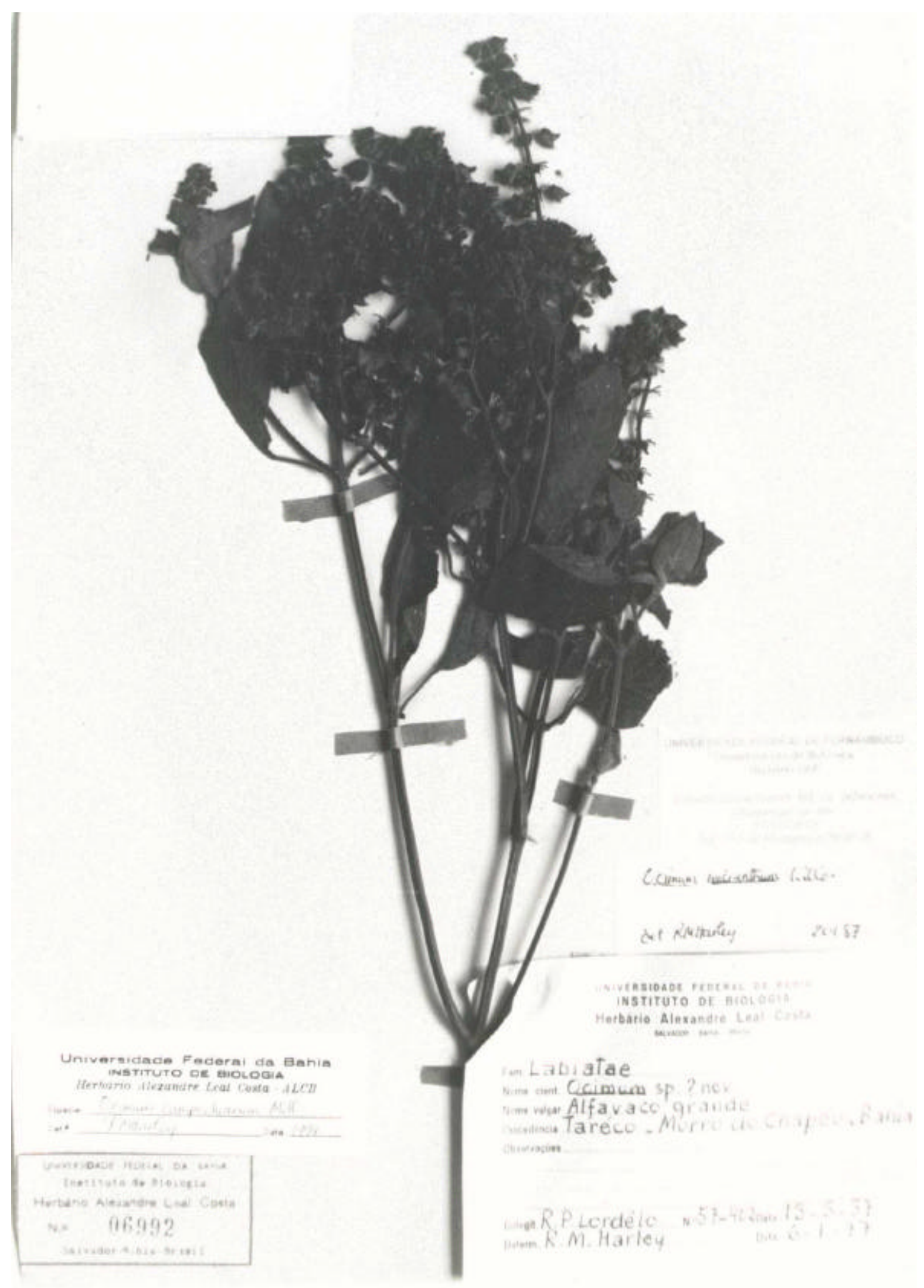

Fig. 2. Ocimum campechianum var. pubescens Albuquerque var. nov. (Holotypus ALCB). 


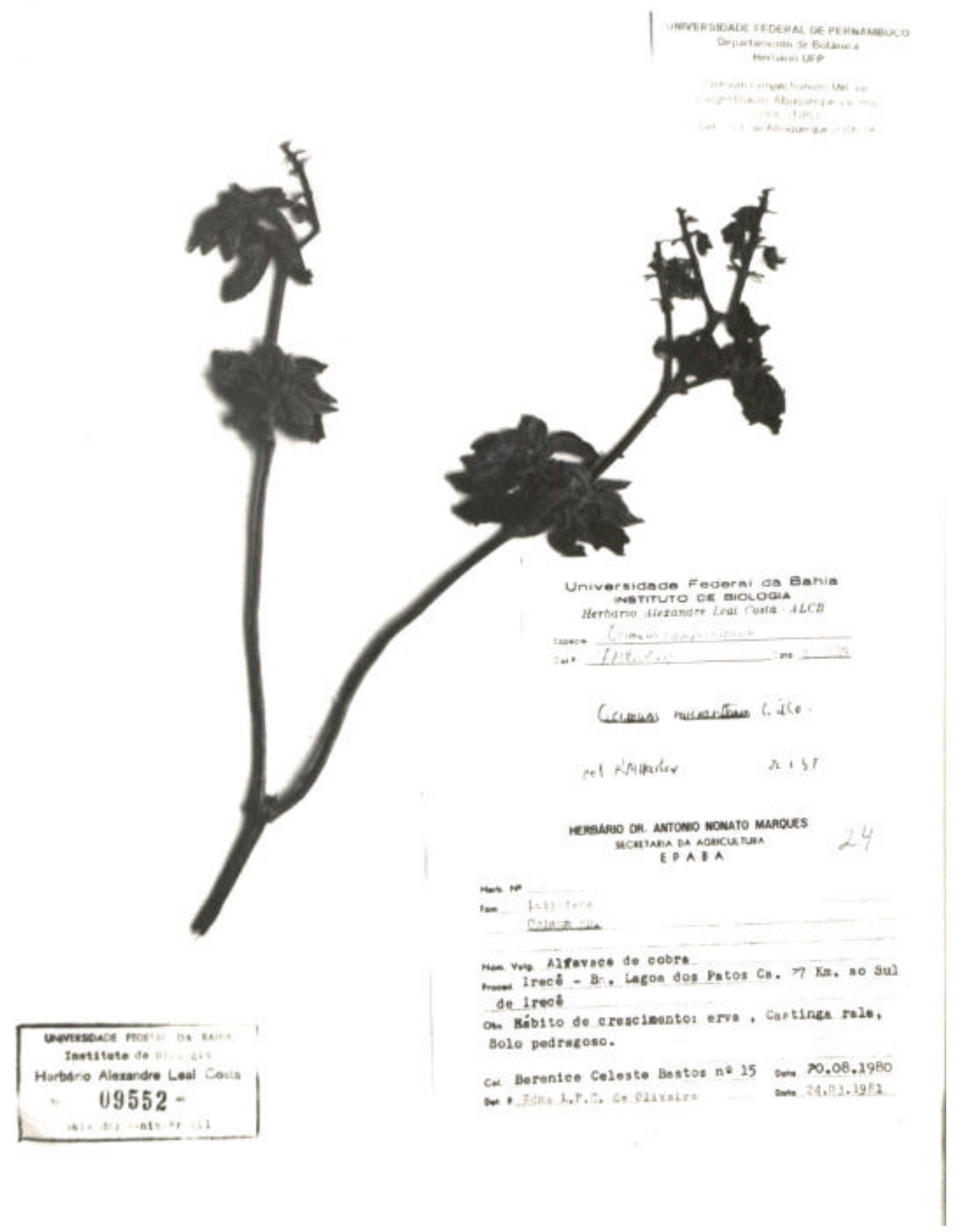

Fig. 3. Ocimum campechianum var. congestifolium Albuquerque var. nov. (Holotypus ALCB). 


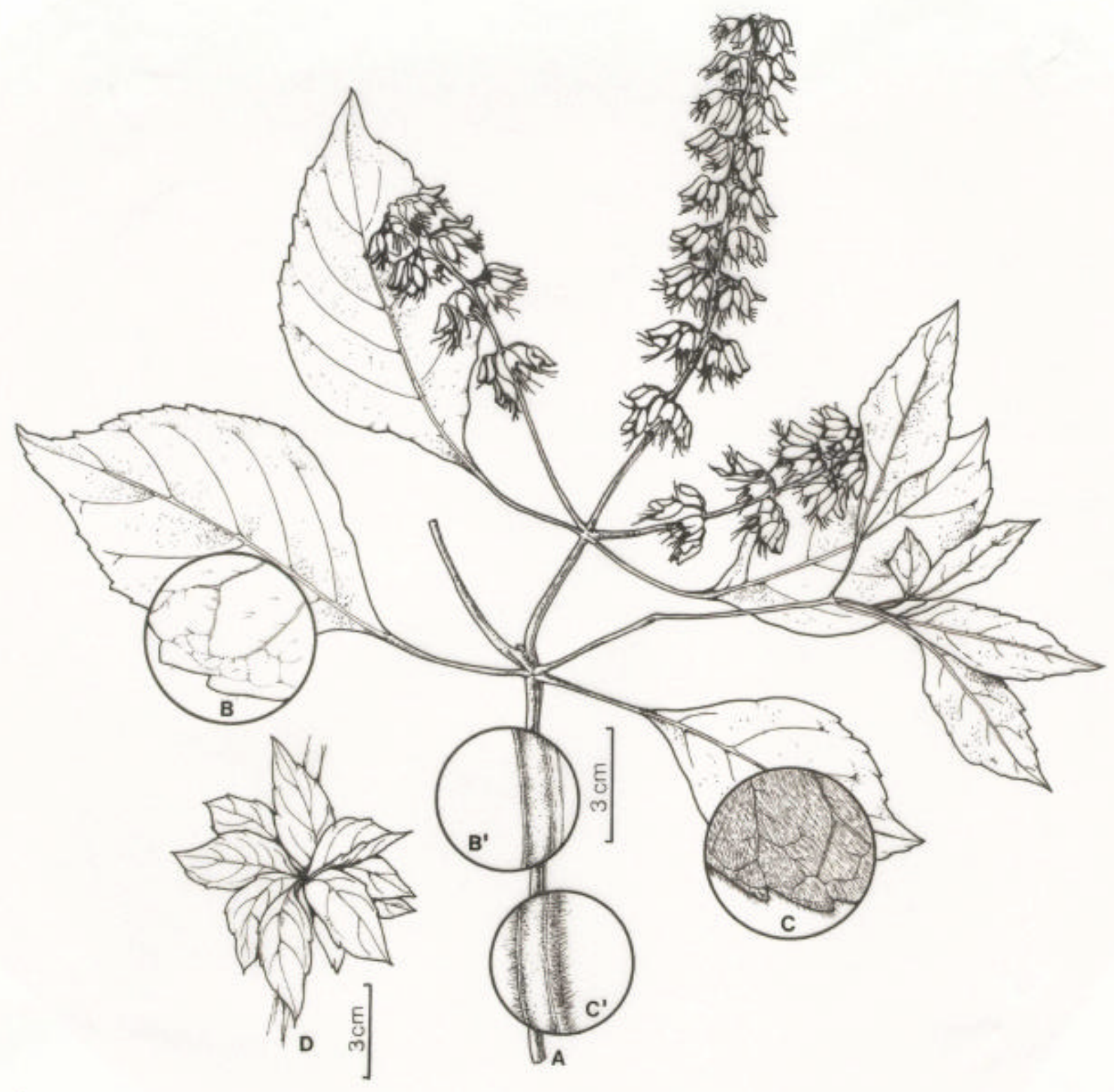

Fig. 4. Ocimum campechianum Mill. A, habit; Leaf (B) and stem (B') indument of the var. campechianum; Leaf $(\mathrm{C})$ and stem $\left(\mathrm{C}^{\prime}\right)$ indument of the var. pubescens (Drawn adapted from Albuquerque \& Andrade, 1998a); D, Leaf arrangement of the var. congestifolium. 


\section{ACKNOWLEDGEMENTS}

I am indebted to Dr. Simon Mayo, Royal Botanic Gardens, Kew, for checking the Latin diagnosis and for translating the English text.

\section{RESUMO}

São descritas três novas variedades no gênero Ocimum, encontradas no Nordeste do Brasil, com base na morfologia vegetativa, hábito, indumento do caule ou pigmentação; são elas: O. minimum var. religiosum Albuquerque var. nov., $O$. campechianum var. pubescens Albuquerque var. nov. e O. campechianum var. congestifolium Albuquerque var. nov.

\section{REFERENCES}

Albuquerque, U.P. \& Andrade, L.H.C. (1998a). El género Ocimum L. (Lamiaceae) en el Nordeste del Brasil. Anales Jard. Bot. Madrid, 56, 43-64.
Albuquerque, U.P. \& Andrade, L.H.C. (1998b). Etnobotánica del género Ocimum L. (Lamiaceae) en las comunidades afrobrasileñas. Anales Jard. Bot. Madrid, 56, 107-118.

Albuquerque,U.P. (1998). Morphological and taxonomical notes on Ocimum transamazonicum C. Pereira. Naturalia, 23, in press.

Holmgreen, P.K.; Holmgreen, N.H. \& Danett, L.C. (1990) Index herbariorum - part I: the herbaria of the world. New York Botanical Garden, New York, pp. 693.

Paton, A. (1992) A synopsis of Ocimum L. (Labiatae) in Africa. Kew Bull., 47, 403-35.

Pereira, C. (1972). Contribuição ao conhecimento da família Labiatae. I . Bradea, 1, 125-28.

Schmidt, J. A. (1858). Labiatae. In Flora Brasiliensis. Munchen, 8, pp.65-226.

Received: September 23, 1997 Revised: November 07, 1997 Accepted: December 23, 1998 